UDK: $2-184.2:: 364.624 .6$

Stručni rad

Primljeno: 14. 8. 2020.

Prihvaćeno za štampu: 5. 11. 2020.

\author{
Dr. sc. Muharem Štulanović, redovni profesor \\ Univerzitet u Bihaću \\ Islamski pedagoški fakultet \\ E-mail:ebuseba@hotmail.com
}

\title{
BOGOBOJAZNOST KAO TERAPIJA ZA STRAHOVE I FOBIJE
}

\section{Sažetak}

Covjek kroz život susréce ili prosto boluje od raznih vrsta strahovanja i fobija kao što su klaustrofobija (od zatvorenih prostora), agorafobija (od otvorenih prostora), akrofobija (od visine), dentofobija (strah od stomatologa), fobija od socijalnih (društvenib) situacija, ksenofobija (strah ili mr:̌nja prema strancima), odredenih životinja, kao što su: zmije, pauci, ptice, miševi, stakori; prirodnih pojava: poplava, grmljavine, leda; krvi i ozljeda; specifičnih situacija kao što je letenja avionom, vožnja liftom itd

Fobije $i$ strahovi mogu biti različitog intenziteta, od malih do smrtnih strahova.

Živimo u savremenom dobu, navikavamo se i patimo od jedne nove vrste planetarne fobije, a to je strah od zaraze koronavirusom.

${ }^{1}$ Fobije se sastoje od trajnih, nerazumnih, jakih strahova (fobija) od situacija, okolnosti ili predmeta. Strahovi izazivaju tjeskobu i izbjegavanje. Fobije se dijele u opće (agorafobija i društvena fobija) i specifične. Uzroci fobija su nepoznati. Dijagnosticiraju se na osnovi anamneze. Agorafobija i društvena fobija se liječe farmakoterapijom, psihoterapijom (npr. izlaganjem, kongnitivno-bihevioralnom terapijom), ili na oba načina. Neke se fobije liječe uglavnom izlaganjem.Vidjeti:

1. Fobije - MSD priručnik dijagnostike i terapije

www.msd-prirucnici.placebo.hr > fo...

2. Dodatak:Popis fobija - Wikipedija

hr.wikipedia.org > wiki > Dodatak:P... 
Uzvišeni Allah spominje strah kao sredstvo iskušenja, ispita pa i kazne. Tako pubanje u rog na Sudnjem danu spominje kao kosmičko budenje osjećaja smrtnog straba koji ce prethoditi unistenju i smrti svih quivih stvorenja:



I u Rog će se pubnuti, $i$ umrijeće oni na nebesima $i$ oni na Zemlji, ostaće samo oni koje bude Allah odabrao (Kur'an, 39: 68);

U komentaru ovog ajeta $i$ kroz tefsirske ekesplikacije navodi se hadis²:

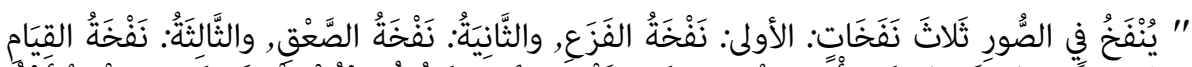

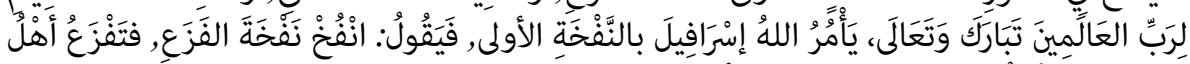

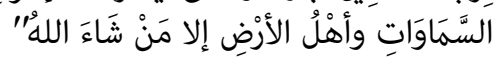

Pubnut ce se u Rog tri puta:

da izazove smrtni strah,

smrt,

ustajanje pred Gospodarem svjetova.

Uqvišeni će narediti Israfilu: - Puši prvo za smrtni strab! Od njega ce se prepasti stanovnici zemlje $i$ nebesa, osim onih za koje Uzvišeni htjedne da se ne prepadnu...

Uzvišni Allah kada govori o iskušenjima na ovom svijetu započinje upravo s vidom kušnje - strahom:

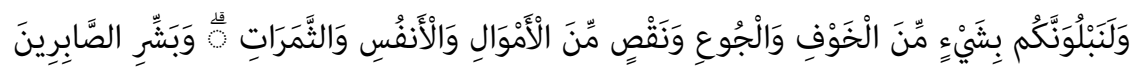
Mi ćemo vas dovoditi u iskušenje malo sa strahom (mrvicom straha, kolicinom koju covjek može podnijeti) i gladovanjem, $i$ time što ćete gubiti imanja $i$ živote i ljetine. A ti obraduj strpljive/ iqudř̌ljive (Kur'an, 2: 155).

U ovom radu ̌̌elimo da progovorimo samo o jednoj vrsti straha koju vjernik treba da posjeduje i osjeća kao poticaj $i$ stimulans svih svojih zivotnih aktivnosti, a to je strah od dragog Boga, strahopoštovanje ili bogobojaznost, bogoštovanje koje osjeća ili treba osjećati spram uzvišenog Stvoritelja! Kada se covjek naoruža s ovim vidom pozitivnog straha, onda nestaju drugi strahovi; strahovi od jakog i nadredenog: direktora, vladara, kralja, predsjednika, ministra, policajca itd. Prema tome, bogobojaznost $i$ strah od Boga je terapija za sue druge vidove fobija i strahova.

${ }^{2}$ Tefsirut-Taberi, komentar sure ez-Zumer, el-aje: 68. 
Ključne riječi: strah od Allaha (havfun minellah), bogobojaznost (hašjetullab), fobija, pozitivni strah, ziker.

\section{Uvod}

\section{(Bogobojaznost je najviši stepen znanja i spoznaje)}

Glava čovjeka/insana je, može se tako kazati, glavni ili najviši dio tijela. Glavna stvar svih stvari na ovome svijetu je islam (رأسُ الأمر الإسلام) kako se navodi u hadisu Tirmizije ${ }^{3}$, a bogobojaznost je najviši stepen znanja i spoznaje, kao što se navodi u suri Fatir:

$$
\text { إِنَّا يَخْشَى اللَّهَ مِنْ عِبَادِهِ الْعُلَمَاءُ }
$$

A Allaha se boje od robova Njegovih - učeni (Kur'an, 35: 28).

Bogobojaznost i strah od Allaha je razlog koji stimulira na iskrenost djelovanja u ime Uzvišenog, kako je došlo o kategorijama vjere, vjerovanja i najvišem stepenu ihsana, kojeg bilježi Muslim ${ }^{4}$ :

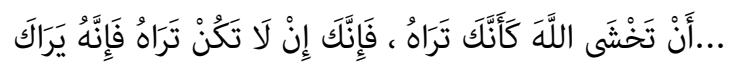

da se Boga bojiš baš kao da ga vidiš, pa iako ga ne možě̌ vidjeti, On vidi tebe.

Znanje i spoznaje se ne mjere samo po količini i mnoštvu nego po bogobojaznosti i svojstvu znalca. Kada su se jednom prilikom obratili imamu Ša'biju oslovivši ga izrazom ,učenjače“ on im kaza: - Znanje $i$ spoznaja su u bogobojaznosti, a Ahmed b. Hanbel kao utemeljitelj jednog od pravnih mezheba i vrhunski učenjak i ekspert u pravu i drugim znanostima, kaže: - Osnova spoznaje/znanja je bogobojaznost.

Bogobojaznost $u$ značenju straha od Boga je naslonjena na znanje/spoznaju i veličanje, a ne samo na količinu ili mnoštvo znanja, jer čovjek kada spozna Gospodara istinskom, neporecivom spoznajom, mora u svom srcu imati strahopoštovanje prema Apsolutu, Kreatoru, Svemogućem dragom Bogu kojem, onda, iskreno upućuje svoje ibadete.

\footnotetext{
${ }^{3}$ Albani ga navodi kao lijepu predaju u Tahridž miškatil-misbah, br.: 28.

${ }^{4}$ Sahihu Muslim, kitabul-Iman, bab: El-islamu, ma huve ve bejanu hisalihi, 1/40. br.: 10 .
} 


\section{Judeokršćanska iskrivljena verzija bogobojaznosti}

Ranije nebeske vjere izgubile su i iskrivile istinsko značenje bogobojaznosti. U židovskim knjigama poslanik Jakub predstavljen je kao onaj „koji se hrve s bogom i gotovo da ga može pobijediti“ dok je u kršćanstvu Isa, a.s., predstavljen kao sami bog, a njegova majka kao bogorodica. Dakle, nema tu ispravnog bogoštovanja ili bogobojaznosti prema Gospodaru i Kreatoru svega.

Uzvišeni Allah navodi da će na Sudnjem danu zbog tog grijeha i iskrivljenosti kršćanske ideologije koja se, naravno, desila poslije uznesenja Isaa, a.s., prozvati na raport i poslanika Isaa, a.s., kako bi se ukazalo na činjenicu da uzoriti poslanik Isa, a.s., nema ništa s takvim iskrivljenjem i takvom ideologijom:

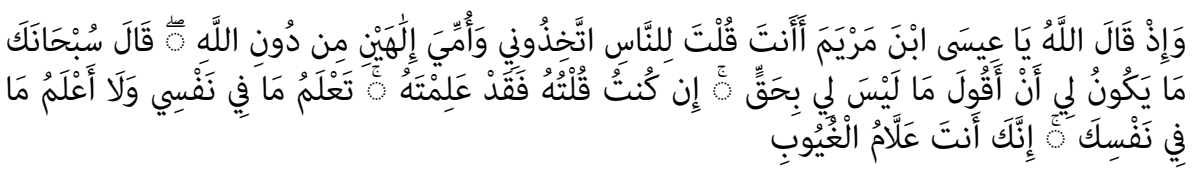

A kada Allah rekne: "O Isa, sine Merjemin, jesi li ti govorio ljudima: 'Prihvatite mene i majku moju kao dva boga uz Allaha!'" - on će reći: "Hvaljen neka si Ti! Meni nije priličilo da govorim ono što nemam pravo. Ako sam ja to govorio, Ti to već znaš; Ti znaš šta ja znam, a ja ne znam šta Ti znaš; Samo Ti jedini sve što je skriveno znaš (Kur'an, 5: 116).

Knjiga Stvaranja u židovskim ,svetim“ tekstovima spominje Ja'kuba da se do zore hrvao sa bogom, koji mu je došao u liku insana, pa kada vidje da ga ne može savladati zatraži mu da ga pusti iz zahvata, rekavši: Pusti me evo zore.

On reče: - Neću te pustiti dok mi ne daš blagoslov.

On ga upita: - Kako ti je ime, a on odgovori: - Jakub.

- Od sada nisi više Jakub nego Israil, jer si se borio sa bogom i ljudima i uspijevao.

Tako je Jakub po toj borbi i hrvanju dobio ime Israil (مصارع الربk koji se s bogom hrvao) što će ostati kao naziv za njegove potomke Izraelićane 
(benu Israil). Dakle, kakvo nakaradno predstavljanje i nepoštivanje Boga kao slabića koji nije u stanju nadhrvati Jakuba ${ }^{5}$.

\section{Strah od Allaha (havfun minellah) i bogobojaznost (hašjetullah)}

Pošto je tema o strahovima i fobijama preobimna, ovdje ćemo se koncentrisati samo na govor o jednom vidu koji može biti terapija za sve druge strahove i fobije, a to je bogobojaznost i strah od Uzvišenog Allaha. Onaj ko se boji i ima strah (havf) pribjegava i oslanja se na bježanje od straha, dok se onaj koji ima strahopoštovanje / bogobojaznost oslanja na znanje, spoznaju i po tome se ravna. Ako bismo to simplificirali, mogli bismo kazati da je strah kad se bojiš od nekoga za koga ne znaš da li si u njegovim rukama ili nisi, ali strahopoštovanje gajiš prema onom za koga sigurno znaš da si u njegovim rukama ${ }^{6}$.

„Bogobojaznost““ je specifičnijeg značenja od izraza „strah od Boga“, ali zbog nemogućnosti da nađemo odgovarajuću riječ u našem jeziku koja bi dala vidljivu jezičku i terminološku iznijansiranost u značenju, u nastavku ćemo ih koristiti uglavnom kao sinonime.

Bogobojaznost je najtananiji i najviši srčani osjećaj na kojem počiva ibadet vjernika, to je srčani ibadet koji mu pomaže u osjećaju da ga Uzvišeni motri kada je u uživanju, samoći i daleko od ljudi. To je najviši osjećaj Božijeg nadgledanja i Njegove sveprisutnosti u životu čovjeka tako da vjernik što više uroni u vode spoznaje svoga Stvoritelja i Gospodara, toliko se poveća njegov osjećaj bogobojaznosti.

Osjećaj straha od Boga se mjeri količinom ibadeta, veličanja i strahopoštovanja prema Kreatoru, Gospodaru i Svevladaru, ljubavi prema Njemu Uzvišenom, poniznosti i služenju insana koje utiče na poticanje ibadeta i ostavljanje zabranjenog. To je pohvalni vid bogobojaznosti koji je naređen $\mathrm{u}$ vjeri i obavezan za prakticiranje $\mathrm{u}$

\footnotetext{
ar.wikipedia.org > wiki > يعقوب - ويكيبيديا posjećeno, august, 2020.

Ove tekstove neki judeo egzegeti tumače da se odnose na duhovne dimenzije u kojima Jakub pobjeđuje suzama i umiljavanjem. Vidjeti:.... التصارع مع الرب في الكتاب المقدس The Greatest. التصا... posjećeno: august, 2020.

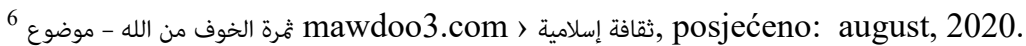


životu vjernika, što je izraz potpunog vjerovanja čija suprotnost je širk i zabranjeno strahopoštovanje koje vodi u neoprostivo krivovjerje.

Zabranjena bogobojaznost je ona koja vodi u očaj i potpuni pesimizam da se ne može udovoljiti Božijim zahtjevima jer Uzvišeni ne opterećuje svoja stvorenja s onim što ne mogu izvršiti i podnijeti.

Strah od Boga je pohvalan i na njemu se temelji istinsko vjerovanje kojem prethodi spoznaja Uzvišenog.

Dvije grane su pohvalnog vida bogobojaznosti:

1. Strah od stajanja pred Uzvišenim, što pretpostavlja svijest čovjeka o Božijem sveprisustvu i Njegovom motrenju i stalnoj mogućnosti dosezanja ili čak svijest i osjećaj da će se doći na Njegov sud eshatološki. Uzvišeni kaže:

وَلَمَنْ خَافَ مَقَامَ ربِبِهِ جَنَّنَان

A za onoga koji se stajanja pred Gospodarom svojim bojao, biće dva perivoja - (Kur'an, 55: 46).

2. Strah od obećane Božije kazne i eshatološkog obračuna koji pretpostavlja vjerovanje i uvjerenje u polaganje računa na kojem će grešnik dobiti zasluženu kaznu po obećanoj prijetnji Uzvišenog:

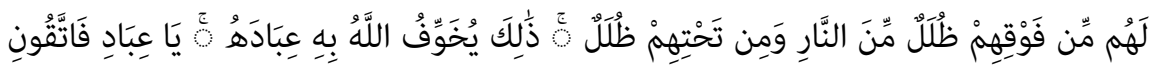
Nad njima će biti naslage vatre, a i ispod njih naslage; time Allah straši robove Svoje. "O robovi Moji, bojte se Mene!" (Kur'an, 39: 16)

Od najizraženijih odlika imana je strahovanje, bogobojaznost ili strahopoštovanje koje čovjek, vjernik, može gajiti prema uzvišenom Gospodaru. A kad je srce vjernika ispunjeno strahom, poštovanjem i bogobojaznošću, stimulira ga na činjenje dobra, izbjegavanje lošeg, oslobađa ga ovosvjetskih, prolaznih želja i pobuda, budeći želju za eshatološkim, vječnim životom kojem stremi u svojim javnim i tajnim aktivnostima znajući da ga Uzvišeni motri i iskušava u svakom trenutku. To je osnova ovosvjetske sreće i budućeg spasa.

- Uzvišeni hvali Svoje poslanike iz razloga što su se samo Njega, svoga Gospodara bojali:

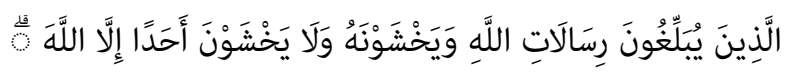


za one koji su Allahove poslanice dostavljali i od Njega strahovali, $i$ koji se nikoga, osim Allaha, nisu bojali. (Kur'an, 33: 39)

U Kur'anu se daje interesantna slika poslanika Musaa, a.s., i njegovog strahopoštovanja i bogobojaznosti ali tek nakon situacije u kojoj Musa traži od Uzvišenog da Ga fizički vidi:

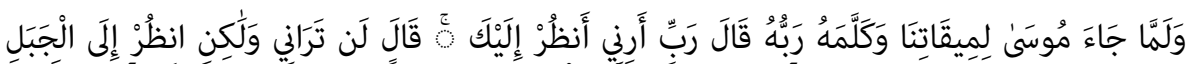

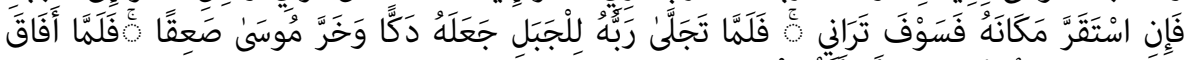



I kad Nam Musa dođe u određeno vrijeme, i kada mu Gospodar njegov progovori, on reče: "Gospodaru moj, ukaži mi se da Te vidim!" - "Ne možeš Me vidjeti" - reče - "ali pogledaj u ono brdo, pa ako ono ostane na svome mjestu, vidjećeš Me!" I kad se Gospodar njegov onome brdu otkri, On ga sa zemljom sravni, a Musa se onesviješćen strovali. Čim se osvijesti, reče: "Hvaljen neka si! Kajem Ti se, ja sam vjernik prvi!" (Kur'an, 7: 143)

Musa nije bio neki slabić pa da se tek tako prepadne, strovali i u 'bandak padne', da ga obuzme strahopoštovanje koje mu ne dozvoljava da išta drugo pita nego da se kaje Uzvišenom i veliča Ga. Naprotiv, kao mladić u naponu snage prije poslanstva pomažući svome sunarodnjaku Izraelićaninu protiv egipatskog Kopta Musa ga ubi nenamjerno. U Kur'anu se spominje izraz: fevekezehu, što može značiti malo ga odgurnuo šakom, nije čak upotrebljen ni izraz darebehu što znači u pravom smislu nekog 'šornuti' i udariti, pa ipak od Musaove sirove snage i udarca ovaj je odmah podlegao. Kur'an kazuje:

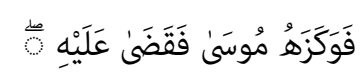

i Musa ga udari šakom i-usmrti. (Kur'an, 28: 15)

Nakon događaja kojem je svjedočio, Musa, a.s., uprkos velike, ogromne, sirove snage i fizičkih predispozicija koje mu omogućavaju da samo jednim udarcem usmrti čovjeka sad odjednom pun je strahopoštovanja i bogobojaznosti!

A kako i ne bi bio jer brda više nije bilo! Od strahopoštovanja je ili u zemlju bestraga propalo, ili po drugim predajama u paramparčad i u prašinu se pretvorilo.

Božije ukazivanje na dunjaluku ništa ne može izdržati i živo opstati. 
Čak, da je samo Kur'an, Njegov božanski govor, objavljen i spušten na planinu, raspala bi se i ne bi mogla izdržati:

Uzvišeni kaza:

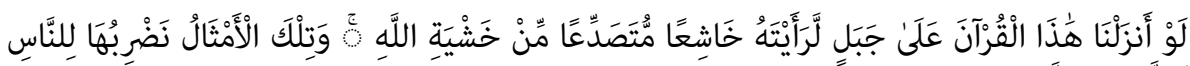

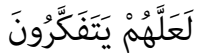

Da ovaj Kur'an kakvom brdu objavimo, ti bi vidio kako je strahopoštovanja puno i kako bi se od straha pred Allahom raspalo. Takve primjere navodimo ljudima da bi razmislili. (Kur'an, 59: 21)

- Uzvišeni obećava i svima onima koji se Boga budu bojali, bogobojaznost i strahopoštovanje prema Uzvišenom Gospodaru gajili da će oprostiti i nagradu im uvećati:

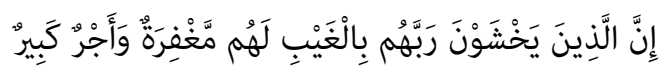

Onima koji se Gospodara svoga boje $i$ kad ih niko ne vidi - oprost $i$ nagrada velika! (Kur'an, 67: 12)

\section{Bogobojaznost kao sloboda i stimulator negriješenja}

- Uzvišeni se opisao s imenima i svojstvima koji izazivaju sve moguće strahopoštovanje i bogobojaznost:

إِنَّ اللَّهَ عَزِيزٌ ذُو انتِقَامِ

- Allah je, uistinu, silan i strog - Osvetnik. (Kur'an, 14: 47)

$$
\text { إِنَّ بَطْشَ رَبِّكَ لَشَدِيدُ }
$$

Odmazda Gospodara tvoga će, zaista, užasna biti! (Kur'an, 85: 12)

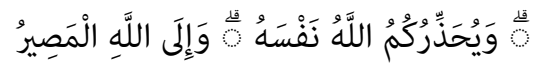

Allah vas podsjeća na Sebe i Allahu se vraća sve! (Kur'an, 3: 28)

- Doći će dan kada se Allahu vraća, kada će se obračunati trun dobra ili trun lošeg djela:

$$
\text { فَمَن يَمْمَلْ مِثْقَالَ ذَرَّة خَيْرَ يَرَهُ }
$$

onaj ko bude uradio koliko trun dobra - vidjeće ga, (Kur'an, 99: 7)

$$
\text { وَمَنَ يَعْمَلْ مِثْقَالَ ذَرَّة شَرَّا يَرَهُ }
$$

a onaj ko bude uradio koliko trun zla - vidjeće ga. (Kur'an, 99: 8) 
Mnogo je razloga za strah od Boga, da se iskaže bogobojaznost i strahopoštovanje prema Njemu Uzvišenom koji je naredio da se mimo Njega Uzvišenog ne bojimo i ne strahujemo od:

1. šejtana i njihovih pristalica:

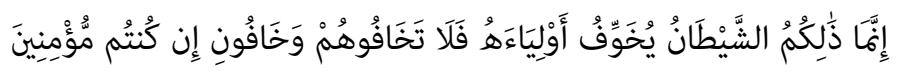

To vas je samo šejtan plašio pristalicama svojim, i ne bojte ih se, a bojte se Mene, ako ste vjernici! (Kur'an, 3: 175)

2. ljudi i njihovih zulumćara:

$$
\text { وَإِيَّايَ فَارْهَبُونِ }
$$

i samo se mene bojte! samo od mene strahujte! (Kur'an, 2: 40)

$$
\text { إلَّلَ الَّنِينَ ظَلَمُوا مِنْهُمْ فَلَا تَخْشَوْهُمْ وَاخْشَوْنِي }
$$

osim zulumćara između njih - njih se ne bojte, Mene se bojte! (Kur'an, 2: 150)

Bogobojaznost kao vrsta pozitivnog straha koju vjernik treba da posjeduje i osjeća stimulans je svih pravih, istinskih životnih aktivnosti gdje se, strahom od dragog Boga koji sve motri, čovjek oslobodi drugih vidova neslobode poslije čega nestaju efekti negativnih strahova, fobija i duševnih bolesti; strah od jakog i nadređenog: direktora, vladara, kralja, predsjednika, ministra, policajca itd., tako da mu istinska bogobojaznost oslobađa njegov mentalni sklop kao lijek. To je, ustvari, duševna (duhovna) terapija protiv svih vidova neslobode, fobija $\mathrm{i}$ strahova.

\section{Strah od grijeha}

Kakva je to pozitivna bogobojaznost i poželjni strah koji sprečava vjernika od djela i aktivnosti koji srde Uzvišenog Allaha? Neke primjere takve bogobojaznosti prepoznajemo kroz kur'anska kazivanja kao strah i bogobojaznost od:

1. širka:



i oni koji druge Gospodaru svome ravnim ne smatraju, (Kur'an, 23: 59) 
2. činjenja svih ružnih i nevaljalih djela koja srde Uzvišenog Gospodara. Allah, dž.š., daje mnogo takvih primjera kroz kur'anska kazivanja:

- strah Jusufa, a.s., od bluda na koji ga poziva žena vladara Egipta:

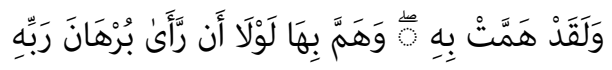

I ona je bila poželjela njega, a i on bi nju poželio da od Gospodara svoga nije opomenu ugledao. (Kur'an, 12: 24)

- strah dobrog Ademovog sina od ubistva. On se Boga boji i kazuje svome bratu koji hoće da ga ubije inoviranjem i izvršenjem prvog ubistva na zemaljskoj kugli:

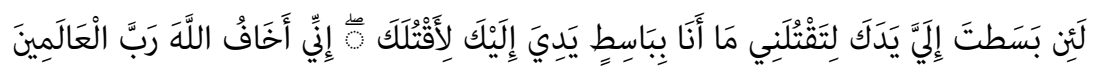

I kad bi ti pružio ruku svoju prema meni da me ubiješ, ja ne bih pružio svoju prema tebi da te ubijem, jer ja se bojim Allaha, Gospodara svjetova. (Kur'an, 5: 28)

- strah neporočne Merjem od grijeha kad joj se, Allahovom odredbom, prikazao melek Džibril u liku najljepšeg mladića u njezinoj sobi. Ukazujući na njenu neporočnost i strah od grijeha Uzvišeni u Kur'anu navodi kako se ona utječe i štiti dovom Gospodaru milostivom:

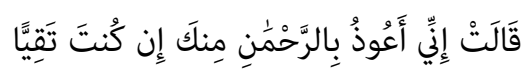

"Utječem se Milostivom od tebe, ako se Njega bojiš!" - uzviknu ona. (Kur'an, 19: 18)

\section{Tradicija praćenja gosta ili putnika}

Ovaj primjer koristimo za jednu korisnu digresiju. Naime, neporočna Merjem u opisanom slučaju bježi u okrilje Božije, u emanet Njemu dovom i oslanjanjem na Njega, Uzvišenog.

Na temelju toga i u našoj tradiciji postoji izreka: - Povjeravam te Allahu na emanet!

To se ustalilo kao običaj, urf i tradicija temeljem hadisa u značenju da onaj ko izlazi iz kuće pa kaže:

$$
\text { إنّيّ أستَودِعَكَكَ أهْلي وماليْ وهذا البيتَ }
$$


Ja Ti (o Allahu) povjeravam svoju porodicu, imetak i ovu kuću; Uzvišeni Allah će sačuvati povjereno mu, inšallah, jer je Mudri Lukman govorio što je došlo u predajama: - Doista Allah, ako mu se povjeri nešto, sačuva ga, i u još jednoj verziji: Allah, ako mu se povjeri nešto, sačuva ga ${ }^{7}$.

Dakle, ako se iskreno prepustiš Uzvišenom, Njega uzmeš za zaštitnika svoje kuće, svoga doma, svoje porodice i sl., onda nema hajduka, poplave, nedaće, nesreće ni požara koji će ti to uzeti.

Tahavi je zabilježio, a i drugi, također, od Abdullaha b. Omera, da je on kada bi ispraćao nekoga rekao bi mu:

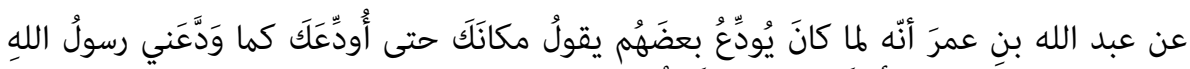

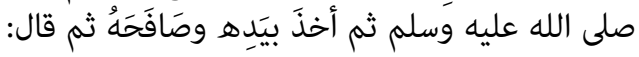

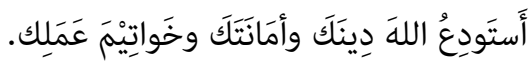

Stani, da te ispratim onako kako je mene ispraćao Allahov Poslanik, a.s. Zatim bi ga uzeo za ruku, rukovao se i rekao:

Povjeravam te Allahu, tvoju vjeru, emanete i tvoje zadnje ovosvjetske aktivnosti.

\section{Bogobojaznost ne pretpostavlja bezgrešnost}

Bogobojaznost ne uslovljava da čovjek bude bezgrešan, nikad ne pogriješi i ne učini grijeh. Strah od Boga znači da kada neko pogriješi onda je od bogobojaznosti da se požuri s kajanjem i istigfarom slijedeći riječi Uzvišenog:

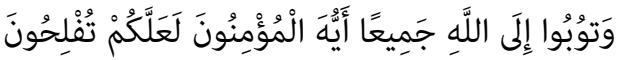

\footnotetext{
${ }^{7}$ Nesai i drugi su to značenje zabilježili kao hadis Abdullaha b. Omera, r.a., koji prenosi da je to Allahov Poslanik, s.a.v.s., rekao:
}

كانَ لقمانُ الحكيم يقولُ إنَّ اللهَ إذا استُودِعَ شَينًا حَفِظَه.

Mudri Lukman je govorio: - Doista Allah, ako mu se povjeri nešto, sačuva ga.

Taberani i Bejheki su, također, zabilježili od Ibn Omera da je čuo Allahovog Poslanika, a.s., kako kaže:

$$
\text { قال سمعتُ رسولَ الله صلى الله عليه وسلم يقولُ: إذا استُودِعَ اللهُ شَييًا حَفظظَه. }
$$

Allah, ako mu se povjeri nešto, sačuva ga. 
I svi se Allahu pokajte, o vjernici, da biste postigli ono što želite. (Kur'an, 24: 31)

Vjernik nikada ne gubi nadu u Božiju milost jer On je Svemilosni:

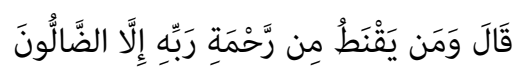

"Nadu u milost Gospodara svoga mogu gubiti samo oni koji su zabludjeli" - reče on. (Kur'an, 15: 56)

A Uzvišeni obećava da će pokajanje primiti:

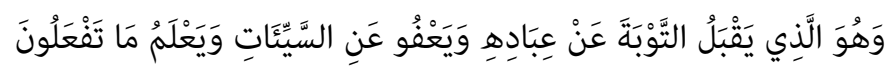

On prima pokajanje od robova Svojih i prašta hrđave postupke i zna šta radite, (Kur'an, 42: 25)

\section{Kako postići bogobojaznost}

Kako se postiže bogobojaznost i kako se srce navikava i trenira na ovaj osjećaj?

1. Učenjem i iskrenim prihvatanjem vjerskog znanja, jer ko više spozna Boga više mu se povećava strahopoštovanje prema Njemu. Uzvišeni kazuje:

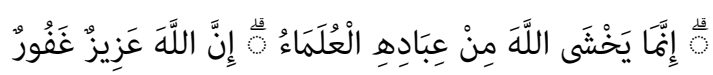

A Allaha se boje od robova Njegovih - učeni. Allah je, doista, silan $i$ On prašta. (Kur'an, 35: 38)

Odnosno, Allaha se ne boje istinskom bogobojaznošću nego ulema koja Ga je spoznala istinskom spoznajom!

Jezički stručnjaci analizirajući ovaj ajet ukazuju na činjenicu da je ovdje upotrijebljeni izraz znalci/ulema subjekat. Dakle, oni se samo Boga boje i od njega strahuju dok je Božije ime Allah objekat ove rečenice došao preciznim božanskim izrazom ispred subjekta iz razloga da se istinska bogobojaznost ograniči samo na istinske znalce, ulemu. A da je subjekat došao prije objekta, kako je uobičajeno u jeziku, onda bi se promijenilo značenje ajeta i glasilo bi da se ulema/znalci samo Boga boje i nikoga drugog, a ovo značenje ne bi bilo tačno jer iz prakse vidimo da je puno državne ili oficijelne uleme u čitavom svijetu koji se više boje svojih nadređenih, kraljeva, diktatora, direktora, itd. nego što se Boga boje. 
Zbog toga je značenje ajeta da se znalci/ulema Boga boje, odnosno ko se Boga ne boji pa i nije pravi znalac/alim.

Naravno, pojam - znalci/ulema ne odnosi se samo na vjerske znalce nego i na sve druge koji Boga spoznaju ${ }^{8}$.

Zbog toga je dovoljno u komentaru ovog ajeta navesti stav Ibni Kesira da se Allaha istinski boje izražavajući svoje strahopoštovanje samo pravi, istinski znalci koji su Ga spoznali, jer koliko god se poveća spoznaja o Veličanstvenom i znanje o Njemu kod nekog toliko se kod njega poveća i strahopoštovanje i bogoštovanje Uzvišenog 9 .

Iz tog razloga, vjersko znanje neprestano učimo, širimo i proširujemo, od dječijih dana u mektebima, pa do obrazovanja i odgoja u medresama $i$ islamskim fakultetima kao što je naš IPF u Bihaću.

2. Od sredstava koja pomažu postizanju bogobojaznosti sigurno su i neke srčane i tjelesne ibadetske aktivnosti kao što su:

- učenje Kur'ana i njegove upute i propise na način da se to čini dubokim poniranjem u značenja i mudrosti kur'anskog teksta, posebno ajeta koji govore o Božijim atributima, kaznama, prijetnjama itd. u skladu s riječima Uzvišenog:

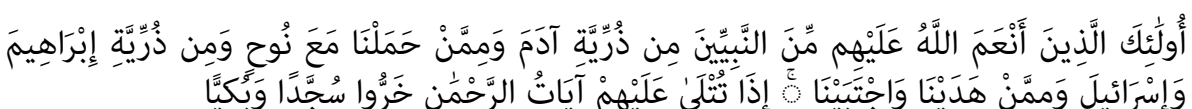

To su ti vjerovjesnici koje je Allah milošću Svojom obasuo, potomci Ademovi $i$ onih koje smo sa Nuhom nosili, i potomci Ibrahimovi $i$ Israilovi, i onih koje smo uputili i odabrali. Kad bi im se ajeti Milostivog čitali, oni bi licem na tle padali i plakali. (Kur'an, 19: 58)

- biti u stalnoj pokornosti Uzvišenom udaljen od Njegovih zabrana i griješenja čime se postiže srčana bogobojaznost. Smatrati griješenje i grijehe užasnim i strašnim, životnom katastrofom koja ga može uništiti. Allahov Poslanik kaže u hadisu kojeg prenosi Ibn Mes'ud, čije je značenje zabilježio i Buharija:

إفا يخشى الله من عباده العلماء.. اعتقاد خاطئ منتشر ... - صدى البلد 8

www.elbalad.news > ...posjećeno, august, 2020.

${ }^{9}$ Tefsir Ibn Kesir, vidi komentar: 35: 38. 
إنَّ المؤمنَ يرَى ذنوبَه كأنه في أصلِ جبلٍ يخافُ أنْ أنْ يقعَ عليه وإنَّ الفاجرَ يرَى ذنوبَه كذبابٍ وقع

Pravi vjernik gleda na svoj grijeh s osjećajem kao da je u podnožju brda koje će pasti na njega, dok se grešnik navikao na griješenje osjeća komotno kao da mu je muha sletjela na nos, pa je ovako plahne te odleti $^{10}$.

3. Zikr i sjećanje na Uzvišenog kada čovjek od strahopoštovanja u samoći zaplače od bogobojaznosti kako je došlo u hadisu o sedmerici koje će Uzvišeni staviti u svoj hlad na Sudnjem danu kada drugog hlada neće biti sem Njegovog, spominjući i:

$$
\text { وَرَجْلُ ذَكَرَ اللَّهَ خَالِيًا فَفَاضَتْ عَيْنَاهُ. }
$$

čovjeka koji se u samoći sjeti Uzvišenog Allaha pa mu oči zasuze.

Spomenuti ,zikr“ može biti jezički ili srčani, ali da to bude u samoći, iskreno, daleko od licemjerja i prijetvornosti pošto je čovjek prijemčiv oponašanju drugih, pa kada se smiju (drugi) smije se, kada plaču i on plače, tako da je samoća i situacija bez prisustva svjedoka najbolja za iskrenost u namjeri i ibadetu.

Naravno, Allahov Poslanik, s.a.v.s., bio je najbolji primjer u tome i njegovi ashabi poslije njega.

Hammad b. Seleme prenio je vjerodostojan hadis po uvjetima Muslima u kojem kazuje da je došao Allahovom Poslaniku, s.a.v.s., kad on klanja dok mu prsa proizvode glasove jecaja kao lonac kada vrije. Ahmed i Nesai su dodali da se radilo o plaču! Zabilježio ga je i Ebu Davud, a ovo je verzija imama Ahmeda:

$$
\text { رأيتُ رسول الله صلى الله عليه وسلم يُصلّي وفي صدره أزيزٌ كأزيز المِرجَل من البكاء. }
$$

Vidjeh Allahovog Poslanika, s.a.v.s., gdje klanja dok mu u prsima jecaji plača podsjećaju na lonac koji vrije $e^{11}$.

\footnotetext{
10 Albani ga navodi kao vjerodostojnu predaju u Sahihut-Tirmizi Buharija ga je zabilježio sa neznatnom razlikom u tekstu (br.: 6308), a ovo je verzija Tirmizije (br.: 2497) i Ahmeda (br.: 3629).

11 Zabilježili su ga peterica autoriteta hadisa, osim Ibn Madže. Ibn Hibban ga cijeni kao vjerodostojnu verziju.
} 
Isto tako i Kur'an hvali bogobojazne koji padajući na sedždu plaču klanjajući se Uzvišenom:

$$
\text { وَيَخِرُونَ لِلَْذَفَْانِ يَبْكُونَ وَيَزِيدُهُمْ خُشُوعًا }
$$

I padaju licem na tle plačući, i on im uvećava strahopoštovanje. (Kur'an, 17: 109)

Na ovoj matrici ponašanja bili su i njegovi ashabi, r.a., kao i prve pravovjerne generacije, koji su određivali stalno vrijeme i termine $u$ kojima su se osamljivali u dobrovoljni vid ibadeta od kojeg se koža ježila i tekle suze u pokušaju da se umile Uzvišenom.

Plač ovakve vrste, nije pokuđen, niti je u osami sadržavao prijetvornost niti vidove licemjerja, nego je kao iskreni vid ibadeta imao ovosvjetske i eshatološke koristi.

Od Ebu Hurejre, r.a., bilježi se kako je Vjerovjesnik, s.a.v.s., kazao:

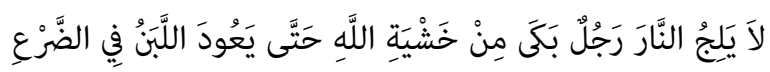

U vatru ne može dospjeti čovjek koji zaplače iz bogobojaznosti isto kao što se ni mlijeko ne može vratiti u vime ${ }^{12}$.

A od Abdullah b. Abbasa, r.a., prenosi se da je čuo Allahovog Poslanika, s.a.v.s., da kaže:

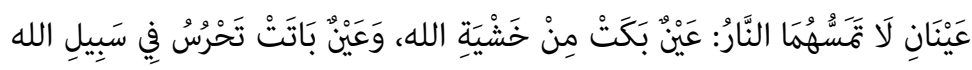

Dvije vrste očiju džehennemska vatra neće doseći: oko koje zaplače od bogobojaznosti i oko koje zanoći stražareći na Božijem putu ${ }^{13}$.

Sjećanje/zikr i spominjanje Uzvišenog Allaha je najjače sredstvo za postizanje bogobojaznosti, blagosti i blagodara srca. Srce zahrđa s nemarom i griješenjem, a čisti se kajanjem i zikrom tako da onaj ko se žali na tvrdoću, okorjelost i brutalnost svoga srca neka preispita svoj odnos prema namazu, zikru i učenju Kur'ana. Ako u tome nema uživanja, onda mora pojačati iskrenost u prakticiranju i promijeniti sav svoj odnos prema ove tri vrijednosti!

\footnotetext{
12 En-Nevevi, Rijadus-salihin, kitabul-Mukaddimat, babu Fadli-l-bukai, hadis br.: 448. Zabilježio ga je Tirmizi u kitabul-Džihad s ocjenom: hasen-sahih.

${ }^{13}$ Zabilježio ga je Tirmizi kao lijepu predaju, a Albani ga je ocijenio kao vjerodostojnu verziju. Kod Ebu Ja'le je zabilježena slijedeća verzija od Enes b. Malika, r.a.:
} 
Mu'az b. Džebel, r.a., spominje zadnje s čime se rastao od Allahovog Poslanika, s.a.v.s., navodi da je bilo pitanje: - Koja su djela najvrednija i najbliža Uzvišenom Allahu?, pa mu je odgovorio:

$$
\text { 《أَنْنَ تَوْتَ وَلِسَانُكَ رَطْبُ مِنْ ذِكْرِ اللَّهِ }
$$

- Da umreš, a jezik ti još uvijek bude svjež od zikra/sjećanja, spominjanja $i$ veličanja Uzvišenog ${ }^{14}$.

Na takav način se postiže i trenira pozitivna bogobojaznost kao terapija za sve druge strahove i fobije. Čovjek ima izbor, hoće li se samo Boga, dragog, bojati uživajući u slobodi monoteizma ili će imati nebrojene druge strahove. Vjernik zna odabrati i napraviti pravi izbor u vidu jedne od najveličanstvenijih i najsadržajnijih dova koju prenosi Ibni Omer, r.a., obuhvata vrijednosti ovoga i onoga svijeta, a koju je Vjerovjesnik dovio sebi i svojim ashabima gotovo u svakom napuštanju i odlasku nakon sijela i druženja:

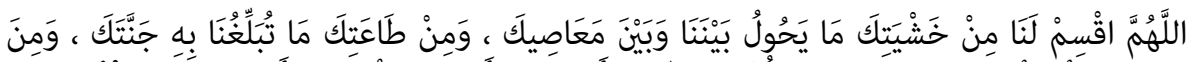

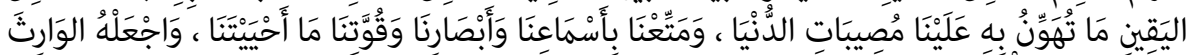



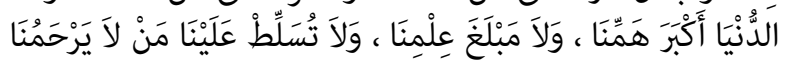

Allahu, dodijeli nam:

- bogobojaznost koja će nam biti zaštita od griješenja prema Tebi,

- pokornost Tebi kojom ćemo doseći Džennet,

- $\quad$ sigurnost koja će nam olakšati ovosvjetske teškoće,

- blagodati - i neka traju: naša čula sluha, vida i snage tijela dok smo na životu,

\section{Allahu,}

- našu osvetu i naplatu ograniči na zulumćara,

- pomozi nas protiv neprijatelja,

- ne dozvoli nam nesreću u vjeri, da nas ovaj svijet okupira i bude osnov našeg stremljenja i spoznaje,

${ }^{14}$ Zabilježio ga je Buharija u poglavlju: Halku ef'alil-ibad. A spominje se kod većeg broja muhaddisa kao slična, vjerodostojna predaja koju prenosi Abdullah b. Busr, r.a. 
- $\quad$ i ne dozvoli da nam vlada onaj ko nema samilosti prema nama ${ }^{15}$.

\section{Rezultati bogobojaznosti i zaključci}

1. Bogobojaznost i strah od Uzvišenog rezultiraju plodovima imana u vidu svojstva koje posjeduju samo iskreni i dobri Allahovi robovi, Njegove muttekije i muhsini koji stalno održavaju praksu sjećanja na Uzvišenog zikrom, sjedeljkama zikra i vjeroučenja;

2. Vrijednost i plodovi bogobojaznosti su vidljivi na pojedincu $i$ čitavom društvu koje se time spašava društvenih bolesti u vidu korupcije, moralnog pada, nepravde, krađe i kriminala.

3. Bogobojaznost se postiže različitim dobročinim aktivnostima, a to svojstvo čuva od upadanja u grijehe i loša djela.

4. Bogobojaznost kao vrsta straha koju vjernik treba da posjeduje i osjeća efikasan je i nenadoknadiv poticaj i stimulans svih pravih, istinskih životnih aktivnosti gdje se strahom od dragog Boga, strahopoštovanjem ili bogobojaznošću, bogoštovanjem koje osjeća ili treba osjećati spram uzvišenog Stvoritelja/Kreatora/Gospodara čovjek oslobodi drugih vidova neslobode i naoruža s nezamjenjivim vidom pozitivnog straha poslije čega nestaju drugi negativni strahovi, fobije i duševne bolesti; strah od jakog i nadređenog - direktora, vladara, kralja, predsjednika, ministra, policajca itd. itd. Prema tome, bogobojaznost i strah od Boga je lijek, duševna i duhovna terapija za sve druge vidove neslobode, fobija i strahova.

5. Ko u traženju znanja iskaže bogobojaznost kao rezultat toga dolazi ljubav, poštovanje i cijenjenje drugih. Istinsko znanje i spoznaja rezultiraju bogobojaznošću koja, ako je prisutna u traženju znanja, manifestuje se tako da čovjek:

- muttekija u svim svojim aktivnostima: teološki/doktrinarno, ibadetski/praktično, etički/moralno, u korespodenciji s drugima itd., iskazuje ono što zna a ujedno i prakticira, što ga čini podobnim za slijeđenje i uzor drugima;

15 Zabilježio ga je Tirmizi (br.: 3502) s ocjenom hasen garib. Albani ga drži vjerodostojnom predajom i navodi u Sahihu Tirmizije. 
- bude spreman na kolektivnu odgovornost, ostavljajući pitanja i tačke razilaženja i neslaganja zarad opće koristi i jedinstva s raširenim prsima u bogobojaznosti od Uzvišenog, podređujući svoj lični ego kolektivitetu, općoj i vjerskoj koristi. Uzvišeni kazuje: $i$ pokoravajte se Allahu i Poslaniku Njegovu, i ne prepirite se da ne biste klonuli i bez borbenog duha ostali; i budite izdržljivi, jer Allah je, zaista, na strani izdržljivih. (Kur'an, 8: 46);

- zna cijeniti ulemu, njihovu vrijednost, čast i ugled u društvu, pozivajući istini na najljepši mogući način i najefektnijom metodom;

- ne donosi fetve bez znanja i argumenata želeći da se pokaže i proslavi;

- bude jednostavan, ponizan i skroman, ne oholi se nad onim koji zna manje od njega, niti zavidi onome ko zna više, jer je nesreća znalca oholost, ekscentričnost i narcisoidnost;

- izbjegava 'jalove' rasprave i licemjerje koje blokira istinu, vodeći čovjeka u pristrasnost, prouzrokujući neprijateljstvo i mržnju;

- gaji svijest o pogubnosti griješenja. To se postiže proučavanjem biografija Božijih poslanika, ashaba i uzimanjem njih kao pravih uzora;

- odgaja svijest o slabosti i nedostatku ljudskih osobina koje treba popravljati;

- sjeća se i podsjeća na historiju naroda koji su završavali uništenjem i s kolektivnim kaznama zbog griješenja i nepokornosti,

- podsjeća se na Sudnji dan i njegove strahote koje će zadesiti grešnike itd., a u isto vrijeme onaj ko se Boga bude bojao bit će spašen i nagrađen kao što se spominje $u$ hadiskim predajama.

Vallahu e'alem!

\section{Literatura:}

1. El-Kur'anu-l-kerim, Mushafu-l-Medinetin-Nebevijjeh, Kur'an Časni, medinska verzija Mushafa; Mudžemme'u-1-melik Fehd, (1405. h. g.)

2. Korkut, Besim, Kur'an s prevodom, S. Arabija, Medina: Štamparija kralja Fehda, (1412. h. g.)

3. The Zekr Project El-Kur'anul-kerim. 


\section{Knjige i brošure}

4. Ahmed b. A'li b. Hadžer El-A'skalani. (1407/1986), Fethul-Bari šerh Sahihul-Buhari.

5. Ahmed b. Muhammed b. Hanbel Eš-Šejbani, (2001/1421), Musned, Muessesetur-risale.

6. Burhanuddin, Ebu-Hasen El-Marginani, El-Hidaje šerh bidajetilmubteda.

7. Ebu Bekr, Ahmed b. Ali El-Džessas. (1992/1412), Ahkamul-Kur'an, Daru Ihjail-kutubila'rebijjeti.

8. Ebu-Zekerijja Muhjuddin b. Šeref en-Nevevi, El-Medžmu'u šerhu-lmuhezzeb (Daru-1-fikr).

9. El-Badži, Ebul-Velid, Sulejman b. Halef, El-Munteka, šerhu-Muvetta Malik, Bejrut: darul-kutubil-i'lmijje.

10. El-Buhuti, Keššaful-kina', Matbe'atus-sunnetil-muhammedijje.

11. Er-Remli, Nihajetul-Muhtadž, Matbea'tul-behijjetil-masrijje.

12. Ibn Džerir Et-Taberi (1984) Džami'u-l-bejan fi te'vili aji-l-Kur'an, Daru-l-Fikr.

13. Ibn-Kesir, (2000) Tefsir Ibn-Kesir, Sarajevo: Visoki saudijski komitet.

14. Ibn Kudame, Abdul-Muhsin Et-Turki i dr. Abdul-Fettah El-Hilv (1992), El-Mugni, Kairo: Hidžr.

15. Ibnul-A'rebi (2003/1424) Ahkamul-Kur'an, Darul-kutubil-i'lmijje.

16. Muhammed b. Ahmed el-Kurtubi (1985) El-Džamiu' liahkami-l-Kur'an, Libanon, Bejrut: Daru ihjait-turasi-1-'Arebi.

17. Muhammed b. Ahmed b. Rušd El-Kurtubi (1988) Bidajetul- mudžtehid ve nihajetul-muktesid, Liban, Bejrut: Darul-kutubil-i'lmijje.

18. Muhammed b. Džerir et-Taberi (1988) Džami'u-l-bejan 'an te'vili aji-lKur'an, Daru-l-fikr.

19. Muhammed b. Idris eš-Šafi'i, El-Umm, Liban, Bejrut: Daru-1-ma'rife.

20. Muhammed Nesib er-Rifa'i (1978) Tejsiru-l-'Alijji-l-kadir lihtisari tefsir Ibn Kesir, Bejrut.

21. Muhammed Nasirud-din el-Albani, Tahridž miškatil-misbah, Amazon.com Services LLC, October 18. 2018.

22. Muhammed Nasirud-din el-Albani (1419/1998) Sahih Sunen TirmiziDai'f Sunen Tirmizi, mektebetul-mea'rif.

23. Ebu Zekerijja en-Nevevi, Rijadus-salihin, (PDF, 20. mart, 2010). 


\section{Internet:}

24. يعقوب - ويكيبيديا

25. ar.wikipedia.org > wiki >يعقوب, posjećeno - august, 2020.

26. https://hr.wikipedia.org/wiki/Dodatak: Popis_fobija, posjećeno - august, 2020.

27. . التصارع مع الرب فى الكتاب المقدس The Greatest...

28. Www.facebook.com > posts > .... We posjećeno - august, 2020.

29. ثقافة إسلامية > mawdoo3.com posjećeno - august, 2020.

إفا يخشى الله من عباده العلماء.. اعتقاد خاطئ منتشر ... - صدى البلد .

31. Www.elbalad.news > ..., posjećeno - august, 2020.

32. الخوف من الله تعالى - طريق الإسلام

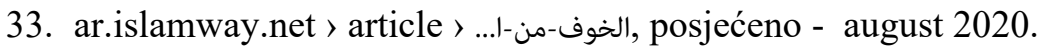

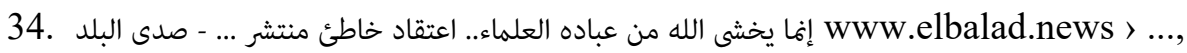
posjećeno - august, 2020.

35. الخوف من الله - شبكة الألوكة

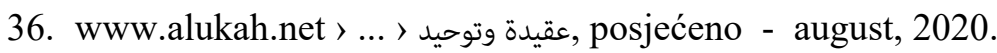


dr. sci. Muharem Štulanović, full professor

University of Bihać

Islamic Pedagogical Faculty

Email:ebuseba@hotmail.com

\section{PIETY AS A THERAPY FOR FEARS AND PHOBIA}

\section{Summary}

Throughout life, a person encounters or simply suffers from various types of fears and phobias such as claustrophobia (from closed spaces), agoraphobia (from open spaces), acrophobia (from height), dentophobia (fear of dentists), phobias from social situations, xenophobia (fear or hatred towards strangers), phobia of certain animals, such as: snakes, spiders, birds, mice, rats; phobia of natural phenomena: floods, thunderstorms, ice; phobia of blood and injuries; phobia of specific situations of flying an airplane, taking an elevator, etc.

Phobias and fears can be of varying intensity, from small to deadly fears.

In modern times, we live, get used to and suffer from a new type of planetary phobia, and that is the fear of being infected with the Coronavirus.

Allah Almighty mentions fear as a means of temptation, trial and even punishment. Thus the blowing of the horn on Judgment Day is mentioned as the cosmic awakening of the feeling of mortal fear that will precede the destruction and death of all living creatures:

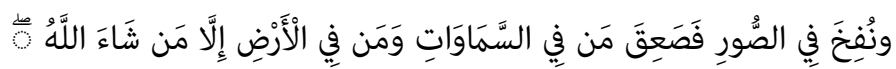

And the Horn will be blown, and those in the heavens and those on the earth will die, leaving only those whom Allah chooses (Qur'an, 39:68);

In the commentary on this verse and through the tafsir explications, the badith is quoted:

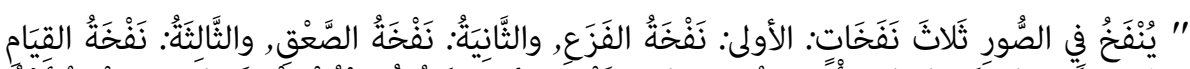





It will be blown into the Horn three times:

1. to cause mortal fear,

2. death,

3. rising before the Lord of the worlds. 
The Almighty will order Israfil: - Blow firstly for mortal fear! The inhabitants of the earth and the sky will be terrified of him, except those whom the Most High wants not to be frightened. When Almighty Allah speaks of the temptations of this world, he begins with the very sight of

the temptation of fear:

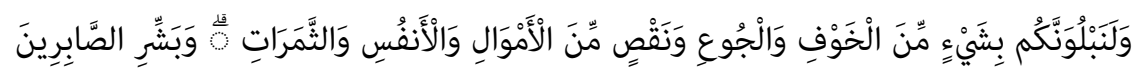

We will tempt you a little with fear (a crumb of fear, the amount a man can bear) and starvation, and by losing possessions and lives and crops. And you please the patient / enduring. (Qur'an, 2: 155).

In this paper we want to talk about only one type of fear that a believer should possess and feel as a stimulus and stimulus of all his life activities and that is fear of dear God, awe or piety, reverence that he feels or should feel towards the exalted Creator! And this is for the reason that when a man arms himself with this kind of positive fear, then other fears disappear; fears of the strong and superior: director, ruler, king, president, minister, policeman, etc. Therefore, godliness and fear of God is a therapy for all other types of phobias and fears.

Keywords: fear of Allah (havfun minellah), piety (hashyatullah), phobia, positive fear, ziker. 


$$
\begin{array}{r}
\text { كلية التربية بيهاتش الإكتور محرم شتولانوفيتشية } \\
\text { الأستامية }
\end{array}
$$

E-mail:ebuseba@hotmail.com

\section{الخشوع كعلاج للمخاوف والرّهاب}

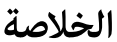

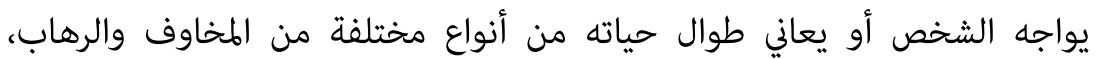

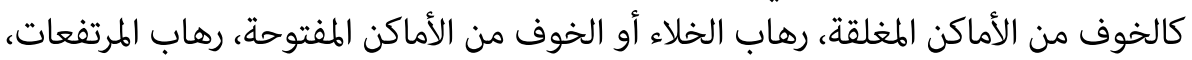

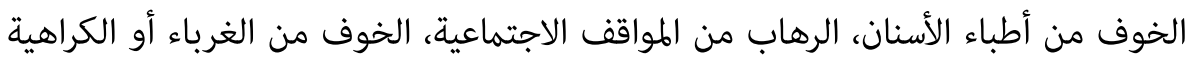

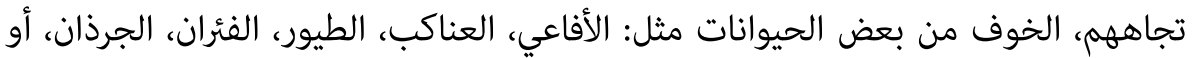

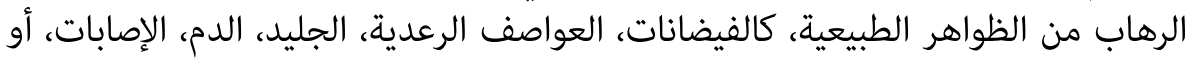

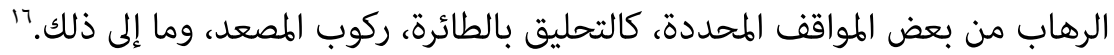

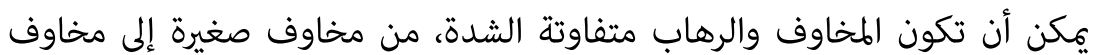


من الإصابة بفيروس كرونا. يذكر الله سبحانه وتعالى الخوف كنوع النور من أنواع الفتنة والابتلاء أو العذاب، ولهذا



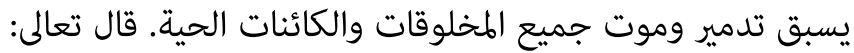

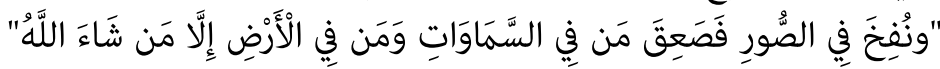

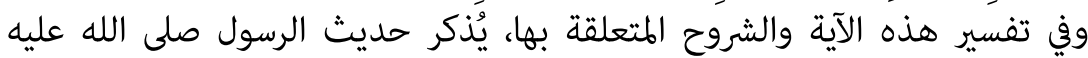



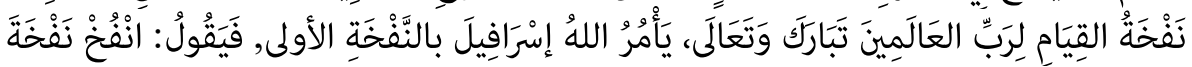

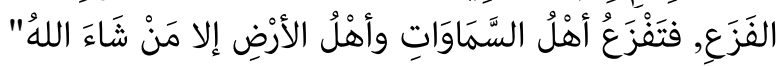

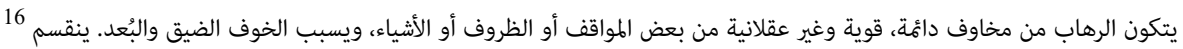

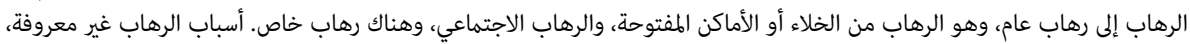

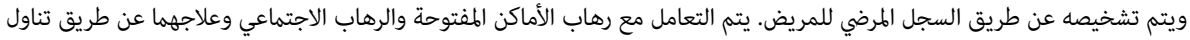


عن طريق التعرُّر. انظر:
}

1. Fobije - MSD priručnik dijagnostike i terapije www.msd-prirucnici.placebo.hr > fo.

2.Dodatak:Popis fobija - Wikipedija hr.wikipedia.org > wiki > Dodatak:P...

تفسير الطبري، تفسير سورة الزمر، الآية ^؟. 17 


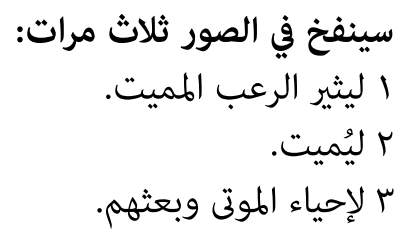

سيأمر الله جل في علاه الملك إسرافيل: انفخ النفخة الأولى لتثير الرعب المميت! فيُصعق من السموات والأرض، إلا من شاء اللهاء اللهاك.

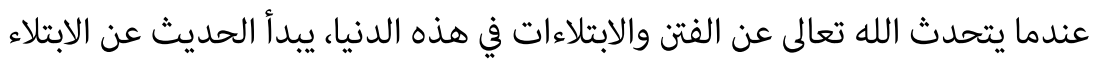

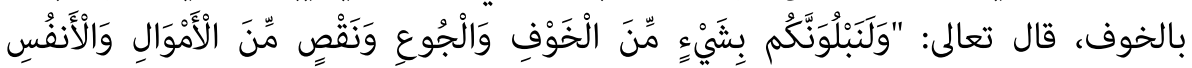

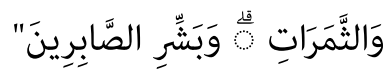

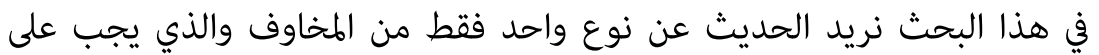



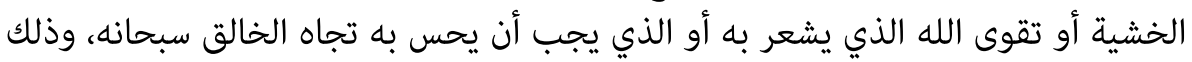

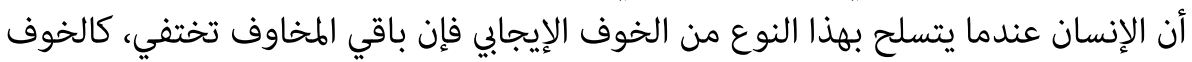

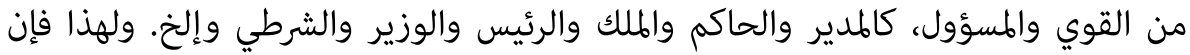

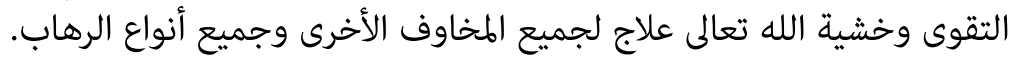

الكلمات المفتاحية: الخوف من الله، خشية الله، الرهاب، الخوف الإيجابي، الذكر. 